\title{
Looking back
}

\section{Insider views on the Judicial Inspectorate for Correctional Services}

\section{Chloë McGrath and Elrena van der Spuy*}

chloemcgrath@gmail.com

Elrena.VanDerSpuy@uct.ac.za

http://dx.doi.org/10.4314/sacq.v48i1.4

The establishment of a constitutional democracy in South Africa necessitated widespread institutional reforms across state sectors. A key feature of such reforms was the emphasis on oversight and accountability as illustrated in reform endeavours pursued in the South African Police Service, courts and prisons. One such oversight mechanism - the Judicial Inspectorate for Correctional Services (JICS) - is the subject of this article. Drawing on qualitative interviews with people closely involved with the JICS since 1998, this article presents 'insider views' regarding the JICS. We conclude with incumbents' views on the effectiveness of the JICS. ${ }^{1}$

\section{In brief: South African prisons}

Under apartheid, South African prisons bore the imprint of racialised and repressive rule. The opportunity for a fundamental re-think of the policy framework had to await the establishment of a constitutional democracy. Bold efforts at redesigning the system of incarceration were put forward, but uneven implementation has diluted many of the visions set out on paper. Twenty years into the new dispensation, South African prisons continue to confront a mix of structural fault lines, bureaucratic intransigence, resource constraints and a measure of political indifference to the plight of prisoners. ${ }^{2}$

In 2001 the Parliamentary Portfolio Committee for Correctional Services called for an independent inquiry in the Department of Correctional Services (DCS) on issues of corruption. In 2006, after five

* Elrena van der Spuy is attached to the Centre of Criminology, Faculty of Law at the University of Cape Town. Chloë McGrath was a researcher attached to the Centre of Criminology in 2013 and has been awarded a Fulbright scholarship for post-graduate studies from August 2014 onwards. years of collecting evidence, the Commission of Inquiry into Alleged Incidents of Violence or Intimidation in the Department of Correctional Services (the Jali Commission) declared that the department was 'arguably no longer governable'. ${ }^{3}$ The report highlighted a wide range of ailments: widespread patterns of corruption in the procurement of goods and services and in appointments, administrative ineptitude, a routinisation of abuse of inmates, widespread sexual violence among inmates, gangsterism, ${ }^{4}$ endemic overcrowding, ${ }^{5}$ and departmental capture by the Police and Prisons Civil Rights Union (POPCRU).

At present the DCS has the capacity to house 118441 inmates across 242 correctional facilities. ${ }^{6}$ The inmate population has long exceeded capacity. The current inmate population of 150608 shows an overcrowding rate of $127 \% .^{7}$ Overcrowding has significantly contributed to poor prison conditions and human rights standards are frequently infringed as a result of the burgeoning numbers of inmates. ${ }^{8}$ In 2013, pre-trial persons constituted $32 \%$ of the total incarcerated population. ${ }^{9}$ 


\section{In brief: the Judicial Inspectorate for Correctional Services}

The Judicial Inspectorate for Correctional Services (JICS) was established in 1998 and became a fully functioning office in 2000. The office is headed up by an Inspecting Judge (IJ), who is assisted by a Chief Executive Officer (CEO), under whom are three units: the support services directorate, the legal services directorate, and the management regions directorate. The CEO must appoint an Independent Correctional Centre Visitor (ICCV) for each correctional facility. The role of the ICCV is to regularly visit correctional centres, interview inmates and record complaints, and attempt to resolve complaints with the DCS where possible, submitting unresolved complaints to the $\mathrm{IJ}$ and writing monthly reports to be submitted to the IJ's office. ${ }^{10}$ Visitors Committees (VC) are then established to deal with unresolved complaints, schedule visits to correctional facilities, and engage with community leaders. The total expenditure of the JICS for the 2012/3 year was R31 321 506.67. In the 2012/13 year, the ICCVs dealt with 530183 complaints across 242 correctional centres. ${ }^{11}$

Four key pieces of research ${ }^{12}$ have evaluated both the necessity for and the efficacy of the JICS. While in agreement that an independent watchdog to provide oversight in South Africa's correctional centres is absolutely necessary, the research has raised serious concerns about its functional independence and its lack of power to enforce recommendations. While the JICS publishes the number of complaints, it does not indicate whether these complaints are resolved. Furthermore, although the JICS has been highly critical of the DCS, its recommendations and findings have been largely disregarded by the DCS.

How do those situated at the upper echelons of the JICS reflect on the mandate, role, achievements and challenges of this oversight mechanism?

\section{Research methods}

This study combined elements of oral history methodology with in-depth interviews. The group of 15 respondents included two drafters of the legislation ${ }^{13}$ in terms of which the JICS was established; six Inspecting Judges, ${ }^{14}$ a former Inspector, ${ }^{15}$ a former Director and a current CEO, ${ }^{16}$ the Head of the Parliamentary Portfolio Committee for the Department of Correctional Services,${ }^{17}$ and three research experts. ${ }^{18}$ The choice of participants proceeded via purposive sampling so as to include all six Inspecting Judges who served terms between 1999 and 2013, and five others who fulfilled key roles in the design and operation of the JICS. Three researchers of prisons provided informed comment on prison reform. The face-to-face interviews of approximately two hours duration each were audio recorded and transcribed during the second half of 2013. All interviewees consented to having their interviews archived in an open access resource.

In the analysis of the interview material we made use of a thematic checklist based on the themes explored in the interviews. The themes included: individual pathways to the Judicial Inspectorate; ${ }^{19}$ key features of South African prisons past and present; core components of the JICS; key moments in the evolution of the JICS; challenges relating to the management of relations and establishing networks; and views on the contribution of the JICS to the democratic administration of prisons. ${ }^{20}$

\section{Key features of prisons past and present}

We asked JICS incumbents to reflect on key features of prisons inherited from the past at the point that reconstruction got underway. The responses served as a reminder of a deeply racialised system, managed along para-military lines, beset by overcrowding and overseen by extremely limited forms of oversight.

Prior to the 1990s, racial segregation in prisons was prescribed in legislation and enforced throughout the country. ${ }^{21}$ One of our interviewees, a former political detainee, described it as follows:

Prior to 1994 of course the first thing was that there was apartheid in prisons. It was very strictly applied. Even the police was more kind of integrated. In the prison apparatus itself, they were very strict. My memory was that all white warders outranked all black warders, no matter what levels they were at. There were no black warders in my white prison. White prisons had beds. At least they had mattresses and they had blankets. Black prisoners had ... well ... not much. ${ }^{22}$ 
The prison service itself was an extremely hierarchical, indeed quasi-military institution. The rank structure was modelled on that of an army, and a coercive top-down spirit pervaded the nation's prisons. Judge Nathan Erasmus observed that this legacy of militarism 'was a force to be reckoned with' as prison reform got underway. ${ }^{23}$

Judge John Trengove, the first Inspecting Judge, commented on the horrendous conditions of inmates when he took up office as follows: 'I was shocked when I became the Inspecting Judge, with the conditions in which people were being held. You had cells which were built and had the facilities to take about, say, 18 prisoners ... where they were crammed and had about 60.'24

Judge Deon van Zyl commented on his own earlier experience: 'In the old dispensation the conditions were really not good. Already in those early days, on circuit courts I visited prisons. It was quite obvious that the cells were hopelessly overcrowded. That's not something of the modern times, that's something that goes back as far as prisons are concerned. ${ }^{25}$

Prior to the introduction of the Bill of Rights and a democratic South Africa, some informal oversight mechanisms for the treatment of incarcerated persons were in place. In 1964, for example, the International Red Cross (ICRC) was invited to visit South African prisons, and conducted inspections across the country, but the report, as is the practice of the ICRC, was not made public. ${ }^{26}$ Furthermore, the Prison Regulations of the Republic of South Africa extended prison visiting rights to all members of parliament regardless of political persuasion, and provided access to judges of the Supreme Court to any correctional facility in the country. Magistrates were given access to prisons within their jurisdiction. Judge Hannes Fagan took this duty seriously: 'Whenever you went on circuit, you always went to the prisons ... it was the duty of the judge to go and visit prisons ... detainees felt that they had nobody to talk to and they couldn't report to anybody. ${ }^{27}$ In contrast, Judge Vuka Tshabalala reported that in his experience judges on the Natal Bench were effectively dissuaded from undertaking such visits due to concerns for their safety. ${ }^{28}$
Several of the respondents recalled human rights abuses inflicted on political detainees from the 1960s onwards. These personal experiences during incarceration shaped a deep commitment to oversight and accountability among them. As Albert Fritz put it:

We always had the theory that the reason why the Mandela regime was so serious about this piece of legislation and specially the part that deals with the Judicial Inspectorate was because they experienced prison life. They know exactly what it was and what conditions were on Robben Island and they really wanted to get some mechanism that was going to be effective..$^{29}$

\section{The birth of the Judicial Inspectorate for Correctional Services}

From 1993 onwards, the courts and politicians, with a cohort of progressive advisers, began to propose sweeping changes regarding incarceration. A groundbreaking court case, Minister of Justice $v$ Hofmeyr, ${ }^{30}$ was the prelude to a human rights regime that included the idea that 'persons incarcerated in prison retain all their personal rights save those abridged or proscribed by law'. ${ }^{31}$

The Interim Constitution explicitly recognised a prisoner's positive rights. ${ }^{32}$ These rights were later entrenched in the Constitution of the Republic of South Africa of 1996. The idea of an independent oversight mechanism for the correctional services arose when the Penal Reform Lobby Group (PRLG), a conglomeration of civil society lobby groups involved in prison reform, spoke out strongly on the inadequacy of a 1994 White Paper issued by the prisons department. ${ }^{33}$ The PRLG argued for an oversight mechanism and pointed out that, without it, the government would be in breach not only of the principles set out in the Constitution but also of Principle 29(1) of the Principles for the Protection of all Persons under any form of Detention or Imprisonment, and Rules 55 and 35(2) of the UN Standard Minimum Rules For the Treatment of Prisoners. ${ }^{34}$

Dirk Van Zyl Smit, an academic who had published prolifically on prison law and practice in South Africa since 1982, was invited by the Commissioner 
of Correctional Services to advise on the new Act. Alongside Van Zyl Smit, drafters Judge Mark Kumleben and Advocate Neil Roussouw considered the models of independent oversight mechanisms in the prison systems of England and Western Australia. ${ }^{35}$

Van Zyl Smit recounted that the advisers considered that the English model was most appropriate for the South African context, but proposed two changes. They argued that a judge should be the head of the institution, based solely on the 'independence and integrity that judges are recognised to have in South Africa'. ${ }^{36}$ In the British system there is both a Prison Ombudsman and an Inspector of Prisons. It was decided that in the light of resource constraints, these should be combined in the single role of the judge within the Inspectorate. The inclusion of 'corrupt and dishonest practices' in the mandate was due to the drafters' conviction that the two were inextricably linked.

The JICS was established under section 25 of the Amendment Act 102 of 1997 of the Correctional Services Act 111 of 1959. The Inspectorate was formally established on 1 June 1998, with Judge John Trengove as the first Inspecting Judge. The Judicial Inspectorate is governed by the provisions in Sections 84 to 94 of the Amendment Act. These sections were promulgated on 8 February 1999, according to the proclamation issued by the President as provided for in section 138 of the Act. ${ }^{37}$

The original mandate of the Inspectorate stated:

The Judicial Inspectorate of prisons is an independent office under the control of the Inspecting Judge ... The object of the Judicial Inspectorate is to facilitate the inspection of prisons in order that the Inspecting Judge may report on the treatment of prisoners in prisons and on conditions and any corrupt or dishonest practices in prisons. ${ }^{38}$

\section{Critical components of the Judicial Inspectorate}

Interviewees were asked about the importance of various components of the JICS relating to the effectiveness of the oversight body. They agreed that the critical components of the JICS were the
Inspecting Judge, the CEO, ICCV and VC, and its electronic systems of recording and analysing data.

\section{The Inspecting Judge}

The Judicial Inspectorate is headed by a judge, who must be either a Judge of the High Court in active service, or a retired judge. In practice the Minister of Correctional Services nominates the Inspecting Judge to the president, who then makes the final appointment. ${ }^{39}$ Due to the recent creation of the position of CEO to replace the former role of the director, most participants did not comment at length about the impact of the CEO. However, it is clear from the data that the administrative function of the director and CEO within the JICS has played a critical role in operationalising the statutory design of the Judicial Inspectorate.

Not all participants agreed that it was necessary for a judge to head up the Judicial Inspectorate, but there was consensus that the status afforded to judges in South Africa was useful in securing the statutory endorsed independence (albeit of a limited kind) of the Inspectorate. As a former Inspector Adam Carelse put it, the Inspecting Judge brought 'independence' and the notion that 'one must account for one's actions'. Other interviewees commented that in the early phase of the Inspectorate's establishment, the position of the judge carried political clout and social prestige. For Judge Nathan Erasmus the immunity of his position as a judge and the security of a lifetime appointment meant that an adversarial approach could be taken when necessary. Judge James Yekiso questioned the reliance on retired judges and suggested that the JICS had to become attractive to judges in active service. Others again insisted that the Inspecting Judge was only as good as his or her commitment to prison reform and the protection of the human rights of inmates.

\section{Independent Correctional Centre Visitors}

There was broad consensus among those interviewed that the Independent Correctional Centre Visitor unit is a critical component of the Judicial Inspectorate. The role of the ICCV, as set out in the Act (S. 93), is to deal with prisoners' complaints by conducting regular visits to the prison, interviewing 
prisoners in private, recording complaints in an official diary and monitoring their progression through the reporting system, and discussing complaints with the Head of Prison or another internal official with the intent of resolving complaints internally where possible. Thus, the ICCV is a critical cog in the system designed according to the principle of procedural justice. It functions via Visitors Committees (VC), consisting of independent persons from particular areas, which are established by the Inspecting Judge. The committees consist of visitors from the relevant area. ${ }^{40}$ The purpose of the VC is to address unresolved complaints that have been reported to the ICCVs with the intention of bringing resolution, and to submit reports with complaints that the committee has been unable to resolve to the Inspecting Judge.

The effectiveness of the lay visitor scheme, designed with the notion of community involvement in mind, is dependent on a range of factors. Viewed collectively, interviewees emphasised the importance of selection, the speedy appointment of 'suitable' lay persons, proper training, adequate resourcing, and ongoing monitoring of visitors at local and regional levels. On these issues respondents concurred with the research findings of external assessments of the ICCV scheme. ${ }^{41}$ There was general agreement that there was much room for improvement to all of these aspects. Chronic problems existed around vacancies, further exacerbated by staff turnover. Above all, it was emphasised that the effectiveness of an individual visitor is largely determined by his or her commitment to the human rights of prisoners. As one interviewee put it: 'If the applicant is a mere job seeker, and someone who sees this as an opportunity, as a stepping stone to something else, then you're not going to get that commitment. ${ }^{\prime 42}$

Did ICCVs make a difference to the lives of inmates? Here the views differed. Some preferred to acknowledge the potential embedded within the system of bottom-up oversight, provided that issues bedevilling selection through to training and monitoring are addressed. Others again had a more pragmatic approach - the 'mere presence' of ICCVs had a 'restraining' influence, creating an awareness that 'big brother' is watching, which in itself may act as a deterrent to perpetrators of human rights abuses. ${ }^{43}$ For another interviewee, the small contribution that individual ICCVs could make to secure, for example, an extra blanket for an inmate, should not be scoffed at. As CEO Adam Carelse put it: 'Now, blankets may sound very petty, but if you were with me last week in the Free State and it's three degrees, and you sleep under one grey blanket, it changes who you are ... and in a centre, there's no one to go to beside the ICCV to ensure that you get that blanket.' ${ }^{44}$

\section{Electronic systems}

Over the past 20 years of criminal justice system reform there has been a considerable investment in the modernisation of information systems. In 2001 the Judicial Inspectorate piloted an electronic reporting system. The system was designed to be the main portal through which ICCVs and Heads of Prisons submitted reports to the Inspecting Judge. ${ }^{45}$ The system was linked to cell phones carried by the ICCVs and other JICS staff to enable more efficient communication. Furthermore, the system was programmed to alert members of staff when reports were submitted to the JICS concerning deaths of inmates, as well as other mandatory reporting incidents such as segregation and the use of mechanical restraints. ${ }^{46}$ In addition to creating an electronic reporting portal, the new IT system also included an automated system for appointing ICCVs, which would, according to Gideon Morris, 'ensure that the system will run independent of the personalities' and thus 'eliminate the incidences of corruption and nepotism'. ${ }^{47}$

However, ten years later the system has not been updated. The website that was launched in 2002 remains the same, and the efficiency of the system has been significantly diminished. More tellingly, both the website and the domain of the JICS are still hosted by the DCS.

\section{Changes in the mandate and role of the JICS}

The mandate of the Judicial Inspectorate as set out in the Act was changed almost immediately after the Inspectorate was officially established. At the request of Judge Fagan, the Act was amended in 2001, and the clause concerning 'corruption and 
dishonest practices in prisons' was removed. ${ }^{48}$ The reasons for removing the corruption clause, set out in the Annual Report, were that the JICS lacked the capacity to track corruption and that the investigation of corruption would compromise relations between correctional officials and JICS staff. It was argued that, given these concerns, corruption should be left to an internal unit of the DCS itself.

\section{Views on the removal of the corruption clause}

The removal of the corruption clause has been controversial, not only in scholarly assessments but also within the JICS. The decision to adopt a 'narrow interpretation' of its mandate has been criticised as disregarding the intimate 'link between corruption (i.e. governance) and the treatment of prisoners (i.e. human rights)'. ${ }^{49}$ The original drafters of the Act who were interviewed insisted that the inclusion of the corruption clause was not an afterthought but a calculated measure to remedy what they perceived to be an omission in the British system of oversight. ${ }^{50}$

Interviewees had divergent views on whether corruption should have been retained within the mandate. There was, however, agreement that the Judicial Inspectorate lacked the capacity to deal with corruption. Judge John Trengove, for example, acknowledged that while he was acutely aware of corruption being rife throughout the ranks of the DCS, limited capacity left him with 'tied hands'. Others again emphasised that the very idea of investigating corruption was also an 'uncomfortable' one as it was bound to strain the relationship between the JICS and DCS. As another interviewee argued:

In Correctional Services the allegations of corruption went to all the way to the top ... how do you investigate and maintain a working relationship? It's very difficult. When you deal with lower cases of soft corruption, it's easy. But when it goes up the hierarchy ... and then tomorrow you have to ask the same people to get your budget. It's not practical. ${ }^{51}$

As it turned out, various scandals relating to corruption made public headlines and then culminated in the establishment in 2001 of the Jali
Commission. Gideon Morris recalls that the JICS was given 'the first bite at the apple' to investigate allegations but that Judge Fagan said, 'We've got so much work to do, we don't have the capacity. I don't want to get involved in that.' 52

\section{The elusive search for independence}

A second issue of importance in the evolution of the Judicial Inspectorate relates to its independence. This matter has been at the centre of the civil society debate. Respondents in this study agreed that the JICS is not functionally independent of the DCS. Financial dependence on the DCS constituted a particular hurdle. According to Judge Trengove, 'as far as the prison department was concerned we were dependent on them for our finance ... we had to get our money from them.'53

\section{Bureaucratisation of systems and processes}

Lastly, a third issue relates to the inevitable but insidious process of bureaucratisation. The routine activities of the foot soldiers (in this instance the ICCVs recording and reporting complaints) can so easily come down to a ticking of boxes on standardised templates, which are then fed into the administrative machinery of the complaints system. More importantly, as interviewees pointed out, lay visitors find it immensely difficult to maintain working relationships with correctional officials and at the same time remain independent in any real sense. It is the problem of 'capture' that is at stake here. ${ }^{54}$ As Fritz put it, 'too quickly the independent visitors also become institutionalised like the warders'. ${ }^{55}$

\section{Managing relationships - external and internal}

The legal mandate of the JICS tells us very little about its actual operation. Key social actors (the Inspecting Judge, the Minister, the Commissioner and senior personnel of the DCS together with heads of prisons, the Parliamentary Portfolio Committee and civil society) need to create working relationships conducive to the realisation of institutional objectives. From the interviews it became apparent that along the way different styles of engagement (more or less adversarial, more or less cooperative) emerged in 
response to situational dynamics and the individual personalities involved.

Three sets of relationships were mentioned by interviewees. The explicit political relationships involve the JICS and the Minister, the JICS and the upper echelons of the DCS, and the JICS and the Portfolio Committee. The bureaucratic/administrative relationships are primarily between the JICS and prison management at regional and local levels, and within the JICS between the Inspecting Judge, the CEO and the ICCVs on the ground. Thirdly, there are the social relationships between the JICS and the wider public, which respondents also commented on as they reflected on the need for establishing legitimacy.

Respondents stated that in the early phase of state reconstruction the JICS could count on the political support of the new government more broadly, and the Ministry of Correctional Services more particularly. At the time, widespread support for the ethos of human rights provided a collective sense of purpose. The 'Robben Island' experience, ${ }^{56}$ shared among many a cadre of new political figures, brought with it a political commitment to the notion of oversight, and thus to the objectives of the JICS. Cordial working relationships between particular individuals (notably Judge Fagan and Deputy Minister Cheryl Gillwald) created further conducive circumstances for cooperation during the first phase of the JICS, but before long the relationships became strained. An adversarial relationship between Judge Erasmus and Minister Ngconde Balfour was brought to a head when Erasmus called in the police to attend to corruption in Pollsmoor. The consequent breakdown in the relationship between the JICS and the Ministry required the new incumbent (Judge Yekiso) to meet the Minister, who outlined the judge's responsibilities as set out in the legal mandate and conveyed that he would 'not appreciate any interference in the performance of my [Yekiso's] duties'. ${ }^{57}$

The reception at prisons of JICS personnel, recalled interviewees, varied from hostile to lukewarm, depending on the area. At times, pro-reform elements within the ranks of the DCS unexpectedly opened up opportunities for engagement. It is in this context of ambiguous support that the office and status associated with the Inspecting Judge was considered a critical factor. Making inroads necessitated cooperative strategies, but in other instances the need for keeping a respectable distance between the JICS and the DCS required something different. Early on, recalled one interviewee, a cadre of new leaders within the DCS wanted too close a relationship with the JICS. They were eager for the JICS to assist with the development of departmental policy, training and developing 'appropriate' budgets. But involvement in operational matters had to be resisted so as to protect the perceived independence of the JICS.

Making unannounced prison visits was a moot point among those interviewed. Some thought it was merely a matter of courtesy to announce visits beforehand. As one Inspecting Judge put it: 'I just regarded it as a courtesy. For instance I mean I know that they want to take a little trouble, to make sure that there is some tea and cookies and samosas or whatever the case may be. ${ }^{58}$ Others again felt that announcing visits beforehand was required in order to minimise the disruption of routine processes. For Adam Carelse, announcing a visit or not was of lesser importance. The real issue was to report on what you found without fear or favour, and not to feel that you had to apologise, as Carelse put it, for saying 'your prison stinks. Just say it as it is. Call them to book. But obviously then you need ... character. You need to be very strong.' 59

Our interviews also explored relationships between the JICS and the Parliamentary Portfolio Committee. Portfolio committees have the potential to fulfil an important oversight function. Under the recent chairmanship of Vincent Smith, both the DCS and JICS were expected to provide quarterly reports to the Portfolio Committee. Some of the respondents commented in particular about the safety of the political space for debate provided by the Portfolio Committee as a multi-party structure. The sophistication of debate and interaction depends very much on the personalities and the commitment of key actors, as remarked on by the chair of the Portfolio Committee. ${ }^{60}$

The quest for managing relationships has lost none of its importance. At a meeting of the Portfolio Committee in August 2013, the working relationship 
between the DCS and the Judicial Inspectorate featured prominently. The concern related to the DCS's claim of not receiving JICS Reports, and the JICS again feeling that its recommendations fell on deaf ears. The chairperson, Vincent Smith, injected a measure of realism into the discussions. There was bound to be tension, he argued, but 'that need not necessarily be destructive. The main issue was to ensure that the tension did not bring work to a grinding halt. ${ }^{61}$

\section{The contribution of the JICS in the greater scheme of things}

At the end of our interviews we asked respondents for their views on the overall contribution of the Judicial Inspectorate to prison administration. Roughly speaking, the responses fell into three categories. One was a kind of qualified optimism about the protection embedded within the constitution and the oversight role of the JICS. A second was deep pessimism about prison conditions and the lack of political commitment to the protection of prisoners' rights. Finally, some respondents attempted to balance the positive achievements of the JCIS with an admission of the difficulties facing the reform of institutions of state.

Judge Fagan's response to the question regarding the overall contribution of the JICS served as a useful reminder that the very concept of prison oversight itself constituted a radical departure from the previous closed system. He also emphasised the rich potential for oversight embedded within the institution at that early period of operationalisation.

A second category of responses consisted of less qualified and more damning responses. Here the responses focused on continuities in the system of incarceration. For Fritz the traumatic memory of his own experience of police detention was evident in his response that prisons remain inhospitable spaces with cruel power inequalities:

I mean from a substantive point nothing ... I think very little changed in prisons. Prison is still about the things that happen all over: the shouts, screams that I heard, that was a police cell, and I can imagine what happens in the truck from the police cell to the prison and what happened at the prison.

For Judge Erasmus the continuity between then and now lies at a deep-seated cultural level where inmates continue to be treated as bandiete. ${ }^{62}$ In his view, although many structural changes have taken place, the mindset of prison wardens remains unchanged. Fritz too pointed out that although the demographic and political affiliation of Correctional Services staff has changed dramatically with the democratisation of South Africa, the attitude towards inmates remains hostile and degrading: '(There is still this attitude that) $\ldots$ a bandiet is a bandiet. He has no rights, he's a criminal.'

A last category of responses we typify as pragmatic realism. These responses see some progress, but underline the complexities in criminal justice reform. Gideon Morris's response emphasised the multifaceted nature of departmental change pursued after 1994.

[Currently the Department of Correctional Services] operates not because of management but despite of management ... I think there are some serious challenges. But that's not uncommon in government as a whole for now.

Many interviewees stressed the enormity of prison reform, and emphasised that issues of overcrowding, health, corruption, coercion and sexual violence are systemically rooted.

\section{Conclusion}

In search of a retrospective account of the design, establishment and operationalisation of the JICS, we relied on the stories and recollections of key incumbents. Through such stories we hoped to breathe additional life into our understanding of the way in which structure and agency interact in processes of social re-engineering. Insiders spoke of both continuities and shifts in the contextual challenges they had to negotiate along the way. But the stories also served as a critical reminder of the force of individual personalities in engaging such challenges.

We were struck by the seriousness and sense of purpose exhibited by almost all of the respondents 
who have helped shape the identity and trajectory of the Judicial Inspectorate over the past decade and a half. Creating an institution from scratch is rarely easy, less so when the institution is charged with powers to inspect internal affairs. Closed institutions - such as prisons - yield particular challenges to bodies of oversight, as the international literature concurs. Such challenges multiply where crisis defines the state of departmental affairs.

Our own small study leads us to concur with much of the recent research literature. Although the JICS is widely acknowledged to be an essential institution in a democratic South Africa, the role of this mechanism of oversight has failed to live up to initial expectations. With varying degrees of emphasis, these 'insiders' appeared aware of the shortcomings of the Inspectorate. For those currently involved, it is a matter of making the best of a difficult situation whose remedy lies quite beyond their powers and responsibilities.

\section{To comment on this article visit}

http://www.issafrica.org/sacq.php

\section{Notes}

1 This research has been funded by the Open Society Foundation. We hereby also acknowledge the comments on earlier drafts that we received from Lukas Muntingh, Gideon Morris, Jeffrey Lever and two anonymous reviewers.

2 Lukas Muntingh, An analytical study of South African prison reform after 1994, unpublished PhD thesis, 2012, 20.

3 E Keehn, N Nyembe and T Sukhija, An evaluation of South Africa's Judicial Inspectorate for Correctional Services assessing its independence, effectiveness, and community engagement, Sonke Gender Justice Network Report, 2013, 7.

4 A Dissel, South African prison conditions: the inmates talk, Imbizo 2 (1996), 4-10.

5 As of 31 March 2011 there were 18 correctional centres in South Africa critically overcrowded at $200 \%$ capacity (Keehn, Nyembe and Sukhija, An evaluation of South Africa's Judicial Inspectorate For Correctional Services, 8).

6 Department of Correctional Services, Statistical information, http://www.dcs.gov.za/AboutUs/Statisticallnformation.aspx (accessed 28 May 2014).

7 Department of Correctional Services, Annual report 2012-2013, http://judicialinsp.dcs.gov.za/Annualreports/ ANNUAL\%2OREPORT\%202012\%20-\%202013.pdf (accessed 2 June 2014).

8 Lukas Muntingh, The prison system, in Chandre Gould (ed), Criminal injustice in South Africa: a civil society perspective, Pretoria: Institute of Security Studies (ISS), 2009, 38.
9 Department of Correctional Services, Annual report 2012-2013, http://judicialinsp.dcs.gov.za/Annualreports/ ANNUAL\%20REPORT\%202012\%20-\%202013.pdf (accessed 2 June 2014), 32.

10 Judicial Inspectorate for Correctional Services, Annual Report 1999, 10.

11 Department of Correctional Services, Annual report 2012-2013, 26 and 47, http://judicialinsp.dcs.gov.za/ Annualreports/ANNUAL\%2OREPORT\%202012\%20-\%20 2013.pdf (accessed 2 June 2014).

12 Muntingh, An analytical study of South African prison reform after 1994, 437; Keehn, Nyembe and Sukhija, An evaluation of South Africa's Judicial Inspectorate for Correctional Services, 7; S Jagwanth, A review of the Judicial Inspectorate of Prisons in South Africa, Research Paper 7 , CSPRI, 2004, 62; J Gallinetti, Report on the evaluation of the independent prison visitors system, Research Paper 5 , CSPRI, 2004; S Wood, An exploratory study of staff capture at the South African Inspectorate of Prisons, International Journal of Comparative and Applied Criminal Justice (2012), http://www.ncbi.nlm.nih.gov/pmc/articles/PMC3348860/ (accessed 20 October 2013).

13 Judge Mark Kumleben and Professor Dirk van Zyl Smit.

14 Judges John Trengove, Johannes Fagan, Nathan Erasmus, James Yekiso, Deon van Zyl and Vuka Tshabalala.

15 Albert Fritz.

16 Gideon Morris, a former Director and Adam Carelse, the current CEO.

17 Vincent Smith.

18 Amanda Dissel, Lukas Muntingh, Chris Giffard.

19 The interviews with key incumbents started on a personal note. We asked respondents about their social and professional backgrounds and how they became involved with the Judicial Inspectorate of Correctional Services (JICS). The life stories were characterised by considerable diversity in terms of background, political experience and worldview. An interesting mix of personal fortune, fate and chance seemed to have combined to either push or pull individuals into the orbit of the JICS.

20 This paper draws on some of the research findings of $\mathrm{C}$ McGrath and E van der Spuy, 'Hier kom die Judge se manne': the Judicial Inspectorate of Correctional Services: a view from the inside, Centre of Criminology, University of Cape Town, October 2013.

21 The Prison and Reformatories Act 1911 (Act 13 of 1911).

22 Interview with Chris Giffard, Cape Town, 19 August 2013.

23 Interview with Judge Nathan Erasmus, former Inspecting Judge, Cape Town, 4 July 2013.

24 Interview with Judge John Trengove, former Inspecting Judge, Somerset West, 13 June 2013.

25 Interview with Judge Deon van Zyl, former Inspecting Judge, Somerset West, 12 June 2013.

26 Department of International Affairs, Prison administration in South Africa, 1969, 30.

27 Interview with Judge Johannes Fagan, former Inspecting Judge, Cape Town, 11 June 2013.

28 Interview with Judge Vuka Tshabalala, current Inspecting Judge, Cape Town, 20 August 2013. 
29 Interview with Albert Fritz, Minister of Social Development, Western Cape Provincial Government, former Inspector in JICS, Cape Town, 8 August 2013

30 Minister of Justice v Hofmeyr (3) SA 131 (A) 1993.

31 Dirk van Zyl Smit, Prisoner's rights, South African Human Rights Yearbook 5 (1994), 269.

32 Dirk van Zyl Smit, Imagining the South African prison, lecture delivered at the University of Cape Town, 2006.

33 Muntingh, An analytical study of South African prison reform after 1994, 393.

34 Jagwanth, A review of the Judicial Inspectorate of Prisons in South Africa.

35 Dirk van Zyl Smit, Regulation of prison conditions, Crime and justice: A Review of Research 39 (2010) 4.

36 Thabani Jali, Commission of Inquiry into alleged incidents of corruption, maladministration, violence or intimidation in the Department of Correctional Services: full report, 2006, 566.

37 Judicial Inspectorate of Prisons, Annual report of the Judicial Inspectorate of Prisons, http://judicialinsp.dcs.gov.za/ Annualreports/annual2000.asp\#3 (accessed 24 June 2014).

38 Correctional Services Act (Act 8 of 1998), S. 85 as amended.

39 Keehn, Nyembe and Sukhija, An evaluation of South Africa's Judicial Inspectorate for Correctional Services, 13.

40 Judicial Inspectorate for Correctional Services, Office of the Inspecting Judge, Annual report 2009-2010, 42.

41 Gallinetti, Report on the evaluation of the independent prison visitors system, 14.

42 Interview with Adam Carelse, past CEO of the JICS, Cape Town, 17 July 2013.

43 Chris Giffard.

44 Adam Carelse.

45 Judicial Inspectorate for Correctional Services, Office of the Inspecting Judge, Annual report 2001-2002, 21.

46 Judicial Inspectorate for Correctional Services, Office of the Inspecting Judge, Annual report 2002-2003, 17.

47 Interview with Gideon Morris, former director of JICS, Cape Town, 14 June 2103.

48 Judicial Inspectorate for Correctional Services, Office of the Inspecting Judge, Inaugural report, 1999, http://judicialinsp. dcs.gov.za/Annualreports/annual2000.asp (accessed 2 June 2014).

49 Muntingh, An analytical study of South African prison reform after 1994, 217.

50 Telephonic interview with Dirk van Zyl Smit, 22 July 2013.

51 Adam Carelse.

52 Gideon Morris.

53 Judge John Trengove.

54 S Wood, An exploratory study of staff capture at the South African Inspectorate of Prisons, International Journal of Comparative and Applied Criminal Justice 36(1) (2007), 45-59.

55 Albert Fritz.

56 A shorthand term that refers to political prisoners' experience of incarceration on Robben Island.

57 Interview with Judge James Yekiso, former Inspecting Judge, Cape Town, 8 August 2013.
58 Judge Deon van Zyl.

59 Adam Carelse.

60 Interview with Vincent Smith, Chairman of the Portfolio Committee on Correctional Services, Johannesburg, 16 July 2013.

61 Minutes of Portfolio Committee of Correctional Services, August 2013, 21, http://www.pmg.org.za/report/20130821department-correctional-services-update-use-consultantsrelationship-judicial-inspectorate-1st-quarter-201314 (accessed 23 April 2014).

62 Literally, bandits. 